\title{
URBAN REGENERATION AND ITS IMPACT FOR SUSTAINABLE CITY DEVELOPMENT
}

DOI: http://dx.doi.org/10.18509/GBP.2020.53

UDC: 332.146.2:711.4(438)

332.146.2:711.4(497.2)

332.146.2:711.4(497.4)

\section{Antonina Atanasova}

Sofia University “St. Kliment Ohridski”, Bulgaria

\begin{abstract}
The processes of globalization, urbanization and the anthropogenic footprint we leave on the natural environment inevitably give rise to a need for action, measures, strategies that lead to the transformation and regeneration of urban areas in order to protect the environment and achieving sustainable urban development.

Urban regeneration is a process that aims to find solutions for important problems in the city and seek to permanently improve the economic, social and environmental aspects of the urban area.

Urban regeneration is suitable for regions with degradation of public spaces, low quality of life, low competitiveness of cities, poor public infrastructure and services, inefficient public transport, massive loss of green spaces, neglected spaces with potential.

Social, economic, natural and technological transformations are also affecting the urban area and thus the urban landscape is constantly changing.

In this report will be presented good practices for urban regeneration from Slovenia, Poland and the main highlight in the article are projects for urban regeneration in the city of Bourgas, in Bulgaria.
\end{abstract}

Keywords: urban regeneration, sustainable development

\section{INTRODUCTION}

In the resent years urban regeneration has become one of the most important targets of European Union. It's a process focused on solving important problems of the city, in order to achieve a vibrant urban environment and high quality of life.

According to Roberts and Sykes (2000) urban regeneration aims to solve urban problems and finding a long-term improvements to the economic, physical, social and environmental aspects of an area to be changed. The most important urban regeneration principles are:

- the need to establish clear and measurable objectives of urban regeneration process and their coherence with the objectives of sustainable development;

- adequate analysis of local conditions;

- the need of the efficiently use of natural, economic and human available resources;

- participation and cooperation among stakeholders, leading to improvement of physical conditions of buildings, social structure, economic base and environmental conditions (Roberts and Sykes, 2000). [1]

Urban regeneration is an opportunity to solve problems such as: lack of identity in residential areas, lack of public spaces and high urban density, which often make it impossible to widen roads, green areas, squares, parks and urban furniture. [2] 
Urban regeneration is a process that tackle physical, social and economic problems in an integrated way. In the literature often many terms are used as a synonymous, such as urban renewal, urban revitalization and etc. Urban regeneration is a form of place management predominantly concerned with the management of the micro spatial processes, but it could be argued that its neoliberal incarnation is preoccupied with the management of perceptions and products to help situate localities at the forefront of the global competition of cities. [3]

Urban regeneration aims to maintain a vibrant downtown economy, as well as to restore the brilliance of backward areas through the introduction of new features in these places. [4]

Cities are transforming by the ongoing economic, social and environmental processes, accompanied by significant structural and functional changes in the urban environment. Together with the residential, industrial, educational, cultural, institutional urban environment, the urban landscape mosaic represents a rather complex structure. In this way, social, economic, natural and technological transformations are also affecting the urban area and thus the urban landscape is constantly changing.

The industrial revolution and population growth in the nineteenth century also accumulated changes. In recent years, economic development, and especially neoliberalism, has taken place in cities, with the main focus to stimulate high economic growth without considering the impacts on our environment. Thus, cities around the world have witnessed neoliberal strategies and policies that first began in North America and Western Europe, and then everywhere, with the hope of harmonizing economic and social policies.

Urban regeneration projects in the nineteenth century mainly aimed at solving problems in industrial cities and maintaining healthy and vibrant areas.

The concept of urban regeneration dates back to the 1950s. However, it has changed significantly since World War II, when many cities faced problems such as economic decline, environmental destruction and social backwardness. After this period, many cities began to concentrate their strategies for development on urban regeneration, revitalization of central areas, reconstruction of backward and residential areas. Thus, the main objective of regeneration projects during this period was to maintain job places through the development of flagship projects located in older, historic city areas of central urban zones, as well as to increase the quality of life.

The main focus of urban regeneration before the 1960s was the eradication of the postwar landscape. During this period many old houses were removed and new processes for revitalization and renovation of urban space began to be initiated. On the other hand, the observed increase in motorway construction leads to an increase in the number of cars. However, during this process, the commercialization of urban centers has also increased and the number of people living in residential areas has decreased as a result of displacement policies and sub-urbanization processes. [5]

In the late 1970s, the city's internal problems, especially those dependent on economic decline and environmental damage, were causing concern in societies. Depending on job losses and rising rental rates, there was an increase in the number of homeless people. Thus, the number of urban regeneration projects was growing in the inner city, because of economic decline, environmental damage, social exclusion, rising unemployment and other social problems. Thus, the projects during this period were mainly focused on the renovation of old urban areas. 
In the 1980s, poor neighborhoods, former industrial districts and old downtown neighborhoods were on the focus of the neoliberal economy.

Urban renewal projects were the most important instruments in the 1990s, especially in European countries, and these projects were put into practice mainly to revitalize, enhance and preserve historic city centers or industrial and commercial centers.

In the XXI century, traditional manufacturing activities began to change and diminish, and processes of de-industrialization had an impact in all cities. Particularly inner-city neighborhoods and traditional urban centers are beginning to lose their identity very quickly. These processes are gradually causing a decline in post-industrial urban areas. These vast abandoned areas have a negative impact on cities and lead to economic decline, environmental degradation, unhealthy urban life, problems with crimes, poverty and more. Recognizing these problems, many governments and communities are beginning to solve these problems, through the regeneration of an old urban areas, abandoned industrial areas, etc., and making them attractive places in the urban landscape. This type of regeneration enables cities to gain a new image.

\section{Good practices for urban regeneration}

The city of Katowice is the main city of the Silesian province and capital of the Upper Silesian Industrial District, an agglomeration of 2.1 million people, in southern Poland. The city itself covers $164 \mathrm{~km} 2$ and has an approximate population of 289,000 people. The historically working-class area has been renowned for its coal and steel production since the 19th century but now the city has undergone a massive redevelopment to become a growing business and cultural center. [6]

One of the model cities, an example of a qualitative transformation from industrialized in the years of socialism to a modern green city today is Katowice in Poland. The city has a population of 294,510 people (2018). For 20 years, Katowice has followed the path from Poland's "ugly duckling" to an ever-renewing city. In the twentieth century Katowice was the center of the coal industry and the industrial engine of Poland, but at the end of the century with the collapse of this industry, it gained the fame of a gray gloomy city that repelled young people and the Poles wanted to forget. The transformation in 20 years has been impressive and today it is considered the most creative city in Poland. [7]

The former industrial area has been transformed into a cultural area with a lot of greenery, which synergistically fits into a modern conference center, the high-tech building of the Polish National Radio Symphony Orchestra, the Museum of Silesia, the Spodek Concert and Sports Arena. [7]

All of these projects were realized without destroying the old sites (except for those posing a threat for people and environment), the transformation process has begun with the planting of a lot of greenery, including the roof space of buildings that today resemble futuristic green meadows, after which is being upgraded and converted into a completely new one, such as the Spodek Arena located on a former coal waste site.

The whole space is filled with mini-gardens, fountains and rock gardens, connected by pedestrian and bicycle lanes, illuminated by energy-saving LED lighting. The Silesian Museum from the outside looks like an entirely green new building, but it is in fact authentically preserved inside and recreates the real cycle of the coal industry. The former main mine was reclaimed and turned into one of the most important museums of modern art in the country.

One of the former manufactory has been transformed into an exhibition hall, which has various art events throughout the year, as an exhibition of innovative modern architectural 
ideas, some of which can later be recreated in the Katowice architectural ensemble, photographic exhibitions and more. The interesting thing is that between the new modern buildings and facilities and the completely renovated old ones in different places there are spots (buildings, facilities) that are authentically preserved, as they were built at the end of the XIX, beginning and the middle of the XX century. Thus, citizens and guests of Katowice can tour the area through architecture through the various stages of Katowice's development. [6]

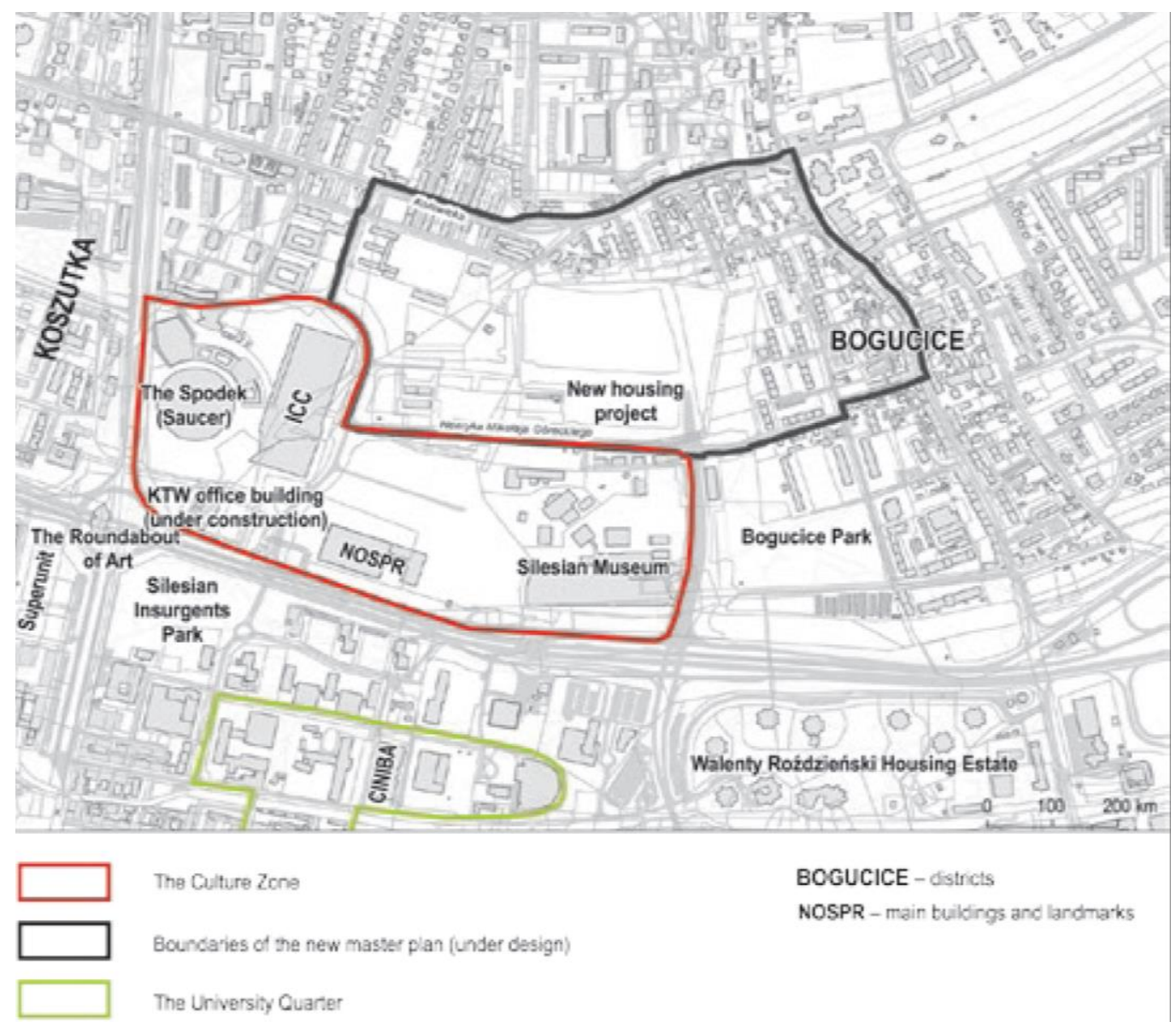

Figure 1. The area of the former Katowice coalmine Source: authors, cartography: http:// www.infokatowice.pl/wpcontent/uploads/2015/10/strefakulturympzp.jpg

Another good example of urban regeneration is the change in the functional purpose of abandoned old industrial buildings. This type of regeneration aims to preserve the historic appearance of former industrial buildings, giving them a new look and function. Such a less well-known example comes from Ljubljana - the capital of Slovenia. The former tobacco factory, located $1 \mathrm{~km}$ away the city center has been completely changed since its closure in 2004. The former tobacco factory was founded in 1871, employing more than 2000 workers by the end of the century, most of them women, since at that time they were viewed as cheap labor and they worked hard in exchange for their remuneration with cigarettes and cigars. [8]

Cigarettes began to be manufactured in 1877 , but the factory did not flourish until after World War II. The Ljubljana Tobacco Factory is also the first in the former Yugoslavia to put cigarettes filters. In 2004, the factory was discontinued. [9] 
The buildings of the tobacco factory, however, still live and there are offices, shops, arts, foundations, museum of tobacco, art studios, which is a good example that it's easy to preserve historical buildings with new functions.

\section{Urban regeneration in the city of Bourgas}

The city of Bourgas is emerging as an important regional center, which performs leading economic, social, cultural, tourist, educational and transport functions. Not only the settlements along the Black Sea coast but also a large part of those in southeastern Bulgaria gravitate around it. The seaside capital of the Southern Black Sea coast hosts many tourists, and is located near attractive tourist centers such as Sunny Beach, Nessebar, Sozopol and others.

The old Marine station (former harbor) has the potential to become a symbol of the city of Bourgas and its surrounding areas. With its central location, deeply embedded in the heart of Burgas Bay, the Marine Station is visible not only from the city but also to the surrounding settlements - from Pomorie to Chernomorets. The Marine Station now is becoming "BURGAS'S EYE", which is visible from the city and the sea.

The Port of Burgas was founded and opened for commercial shipping in 1903. In the resent years the Marine station has been transformed significantly. From the former harbor to modern public access area. This has been achieved through recreational functions, cultural functions, commercial functions.

First step in the process for urban regeneration in this area became in the 1990's. The idea of opening the city of Bourgas to the sea has been the subject of debates for a long time. In the urban development of the General Spatial Plans of the City of Bourgas since 1978, 1984. In 1992, the territory of the Port of Bourgas was intended in part to create a direct connection between the central city part and the sea. The socio-economic conditions, as well as the actual workload of the port complex, have always been a serious obstacle to the realization of this idea. The administration of Port Bourgas EAD and other Bulgarian experts started in 1992 comprehensive studies for the reconstruction and development of the Port of Burgas - process of urban regeneration. [10]

In the period 1994-1996 a number of pre-investment surveys for different port areas were also commissioned and prepared. All the accumulated expertise and experience found their expression in the development in 1996 of the Master Plan for Development of the Port of Burgas with period 1997-2015.

In the last 10 years the Marine Station was transformed in public access area. The construction of the Marine Station provides an opportunity to be realized the concept of opening the city to the sea, outsourcing industrial activities and restructuring the coastal industrial zones and defining new public service areas.

The architectural design of the new station building allows, in addition to its main function, public events (exhibitions, concerts, exhibitions, etc.) to be held there.

One of the first structures erected here is a bulk cargo storage facility. The builder of the facility is a French company. Its name is MAGAZIA 1. The technology with which it is implemented is very interesting. This fact, combined with the age of the building: a whole 112 years - and gives the status of an authentic historical landmark.

This historical building has been transformed and today, it collects and offers a variety of culinary experiences - for every taste and occasion, because everything is tastier on the beach.

The last idea for this zone is to be installed mirror planetarium through which people and kids will have the ability to experience, through $3 \mathrm{D}$ projections, the magic of the night 
sky and the mysteries of the vast cosmos that often remain hidden from our eyes. With the help of specially developed science and software programs, the secrets of the starry sky will be revealed to take visitors on a space trip to near and far planets and galaxies.

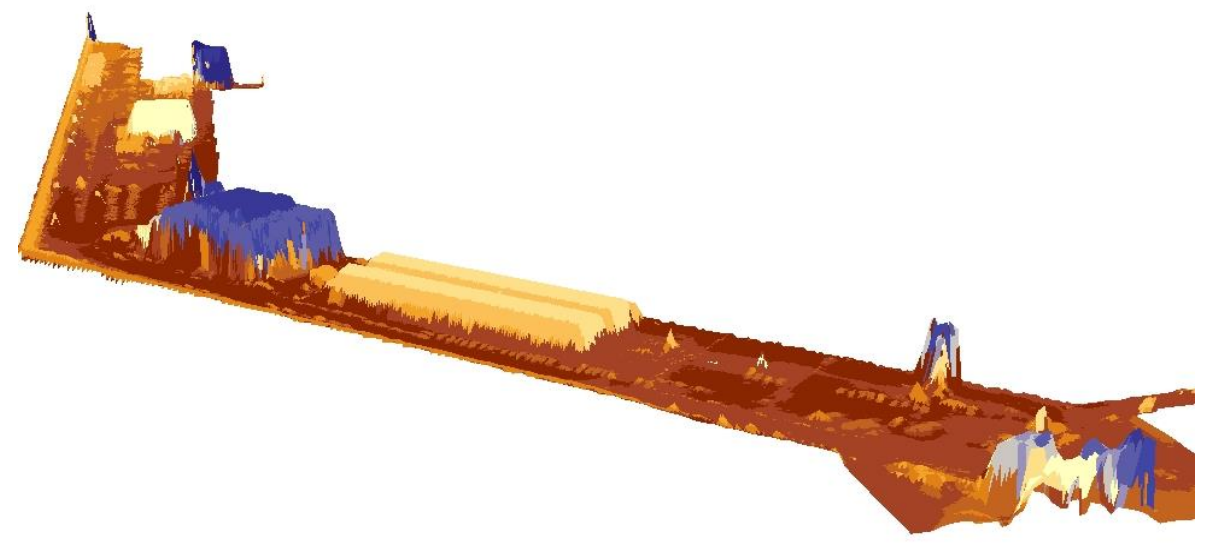

Figure 2. 3D model of the Marine Station, the city of Bourgas Source: Arc GIS, own research

\section{CONCLUSION}

Urban regeneration is an important process that ensure the rehabilitation of the old industrial spaces and buildings, places with the lack of identity, greenery, and change the functions of these places in order to give them a whole new identity. This is a very important task and influences on the sustainable development of the cities.

In this article was showed good practices and projects from Katowice, Bourgas and Ljubljana, which are evidence for how cities with different problems, lack of identity can change functions of these places, which is a powerful tool for sustainable development in the city areas.

\section{REFERENCES}

[1] Roberts, P., Sykes, H., "The evolution, definition and purpose of urban regeneration", Urban regeneration. A handbook. Sage 2000, p.17, p.18

[2] Alpoli, Ch., (2013) Integrated Urban Regeneration - Solution for Cities Revitalize, International Economic Conference of Sibiu 2013 Post Crisis Economy: Challenges and Opportunities, IECS

[3] Lovering, J. (2003), 'MNCs and wannabes: Inward investment, discourses of regional development, and the regional service class', in Phelps, N. and Raines, P. (eds) 'The new competition for inward investment: Companies, institutions and territorial development', Edward Elgar, Cheltenham, pp. 39-60.

[4] Bakir, N., Project based-urban renewal and transformation of urban landscape in Turkey, Intechopen

[5] Ozden, P. (2012), Culture-led regeneration projects in post-industrial areas: The Istanbul Experience, The Sustainable City VII, Vol. 2

[6] https://urbact.eu/katowice

[7] Gwosdz, A., Gwosdz, K., "Katowice effect"? Regeneration of the site of the former Katowice coal mine through prestige cultural projects, Urban Development Issues, vol. 56, pp. 27-40, DOI: 10.2478/udi-2018-0010

[8] http://www.tobacna.si/en/company/history

[9] https://www.slonnect.com/slovenias-tobacco-giant/

[10] https://port-burgas.bg/istoriya 